\title{
The effect of selected rumen fauna on fibrolytic enzyme activities, bacterial mass, fibre disappearance and fermentation pattern in sheep*
}

\author{
T. Michałowski, G. Bełżecki, E. Kwiatkowska and J.J. Pająk
}

\author{
The Kielanowski Institute of Animal Physiology and Nutrition, \\ Polish Academy of Sciences \\ 05-110 Jabtonna, Poland
}

(Received 16 September 2002; accepted 20 December 2002)

\begin{abstract}
Three Polish Merino wethers, fed hay and ground barley, were defaunated and then faunated with Eudiplodinium maggii only; with Eudiplodinium maggii and Entodinium caudatum or with both opryoscolecids and Dasytricha ruminantium. The total number of ciliates varied in the range of $16-403 \times 10^{3} / \mathrm{g}$ rumen content depending on the experimental period. Total bacterial contributed to $12.7-19.6 \% \mathrm{DM}$ of rumen digesta. The bacterial matter in two of three sheep was negatively influenced by Entodinium caudatum and Dasytricha ruminantium while the effect of Eudiplodinium maggii was positive. The establishment of ophryoscolecid ciliates in the rumen resulted in an increase in both $\mathrm{CMC}$-ase and xylanase activities $(\mathrm{P}<0.01)$, while the appearance of Dasytricha ruminantium was accompanied by a decrease in xylanolytic activity. A positive relationship was found between the numbers of Eudiplodinium maggii and both $\mathrm{CMC}$-ase and xylanase activities $(\mathrm{P}<0.05)$ irrespective of the presence or absence of other protozoa in the rumen. It was calculated that $8-38 \%$ of the activity of CMC-ase and $14-49 \%$ of xylanase in the rumen originated from Eudiplodinium maggii. The quantities of dry matter, ADF and NDF that disappeared from the rumen within $12 \mathrm{~h}$ after feeding were $0.62-0.83,0.18-0.32$ and $0.32-0.54 \mathrm{~kg}$, respectively.

Establishment of Eudiplodinium maggii in the rumen was accompanied by increased disappearance of DM, ADF and NDF in only one of three animals. A decrease in disappearance of DM, ADF and NDF was observed following the establishment of Dasytricha ruminantium in all three animals.
\end{abstract}

* Supported by State Committee for Scientific Research, Grant No 5 P06E03615 
The concentration of acetic, propionic and butyric acids was within the ranges of 5.25-7.94, $1.29-2.34$ and $0.75-1.39 \mathrm{mM} / 100 \mathrm{ml}$ of rumen fluid, respectively. Acetate and propionate were the lowest in the sheep with the established population of Eudiplodinium maggii, whereas butyrate, in animals with all three ciliate species in the rumen. The highest concentration of acetic acid was observed following establishment of both entodiniomorphid species, while that of butyrate, in sheep inoculated with Eudiplodinium maggii. The production rate of acetate, propionate and butyrate was 21.3-24.5, 4.7-6.6 and 2.8-5.6 $\mu \mathrm{M} / \mathrm{g}$ rumen contents/h, respectively. Production of acetic acid was not influenced by protozoa. An increase in the production rate of butyrate at $4 \mathrm{~h}$ after feeding was found after establishment of Eudipoldinium maggii in the rumen. Appearance of Entodinium caudatum and Dasytricha ruminantium decreased the production of butyrate at $4 \mathrm{~h}$ after and propionate just before feeding, respectively.

KEY WORDS: rumen ciliates, CMC-ase and xylanase activities, fibre digestion, VFA concentration, VFA production

\section{INTRODUCTION}

Ruminants depend on bacteria, fungi and protozoa for the utilization of energy from fibrous feeds. It is well documented that an important part of the $\beta$-endoglucanase and xylanase activities is of protozoan origin (Coleman, 1985; Michalowski and Harmeyer, 1998). The extent to which the ciliates are directly involved in fibre digestion is, however, not known. The natural ciliate fauna in the rumen consists of many species and only some of them can play a role in the ruminal fibrolysis whereas the most cellulolytic seem to be Eudiplodinium maggii, Epidinium ecaudatum and Ostracodinium dilobum (Dehority, 1993). The most numerous species in the rumen, i.e. Entodinium does not contribute directly to fibre degradation, but it is able to affect positively fibrolytic bacteria (Ushida et al., 1991). The role of the rumen Holotricha is not well determined. For example Ushida et al. (1991) are of the opinion that these ciliates negatively influence ruminal fibrolysis, while Jounay et al. (1995) found a positive effect of Isotricha on DM and ADF digestibility in the rumen of monofaunated sheep. Recently Ivan et al. (2000) examined NDF digestion in monofaunated sheep and among others with either Dasytricha or Isotricha. The authors found that the diet is an important factor influencing the obtained results. It is noteworthy that we found no reports on such a study with ruminants selectively faunated with fibrolytic species in the available literature.

It was found in an in vitro experiment that Eudiplodinium maggii ciliates readily engulfed, digested and fermented hay (Michalowski, 2001). Taking this as a starting point we decided to measure fibrolytic enzyme activity, disappearance of fibre components and fermentation activity in the rumen of wethers faunated with either this fibrolytic species of rumen ciliates alone or together with other protozoa that prefer starch or soluble carbohydrates. 


\section{MATERIAL AND METHODS}

\section{Animals, feeds and feeding}

Three Polish Merino wethers fitted with large ( $\sim 10 \mathrm{~cm}$ ID) rumen fistulae were used. The animals weighed between $40-43 \mathrm{~kg}$ at the beginning of the experiment and were kept in individual pens with solid woody walls. No contact per os between animals was possible. The sheep were fed $750 \mathrm{~g}$ meadow hay and $130 \mathrm{~g}$ ground barley per meal at 8.00 and $20.00 \mathrm{~h}$; water was available all the time. Dry matter (DM), ADF and NDF contents in hay were 89.3, 40.1 and 57.4 and in barley 87.1, 6.8 and $48.4 \%$, respectively.

\section{Experimental procedure and sampling}

The study consisted of 4 experimental periods during which the sheep were either ciliate free (period I) or refaunated with only Eudiplodinium maggii (period II); with Eudiplodinium maggii +Entodinium caudatum (period III) or with both ophryoscolecids + Dasytricha ruminantium (period IV). Each period was divided to two sub-periods.

The first sub-period began with either defaunation (period I) or inoculation of successive species of ciliates into the rumen of sheep (period II, III and IV) and was applied as a period necessary for the newly inoculated microorganisms to become established. The adaptation periods always lasted for a minimum of 3 weeks (according to Jouany and Ushida, 1990) with an exception for experimental period IV as Dasytricha ruminantium required more than 2 months to become established. The sheep were defaunated as described by Michalowski et al. (1999). The ciliates Eudiplodinium maggii and Entodinium caudatum were isolated from the rumen of other sheep and cultured in vitro (Michalowski et al., 1991) in one species population before inoculation into the rumen. The protozoa Dasytricha ruminantium were isolated from the rumen fluid of cow and introduced immediately into the rumen of sheep. No less than 100 individuals were present in each inoculum, while inoculation was repeated several times.

The second sub-period comprised both samplings of the rumen digesta and measurements of the production rate of VFA. It lasted for about 2 months. Rumen contents were sampled to determine the protozoa numbers $(5 \mathrm{~g})$, bacterial mass, fibrolytic enzyme activities and dry matter $(60-70 \mathrm{~g})$ as well as production rate of VFA (20 g). Rumen fluid samples $(5 \mathrm{ml})$ were taken simultaneously to measure VFA concentration. The samples were collected just before the morning (8.00) and evening (20.00) feedings as well was at noon and at $4 \mathrm{~h}$ thereafter. Each sample was taken in duplicate, while each sampling was repeated three times on three different days. 
To ensure the representative character of the samples they were collected either following evacuation and precise mixing of whole rumen digesta (samples collected just before the morning and evening feedings) or after withdrawing and pulling of numerous samples of the contents from different places in the rumen $(1-2 \mathrm{~kg}$ total weight) followed by precise mixing and sampling (samples taken at noon and $4 \mathrm{~h}$ later). The material remainding after sampling was immediately returned to the rumen. Sampling was performed only once a day and a break not shorter than 3 days was always applied between two successive samplings.

The weight of the rumen content was estimated just before the morning (8.00) and evening (20.00) feedings. For this purpose all of the digesta was evacuated from the rumen, weighed and sampled (see above) and returned as soon as possible. Evacuation of the rumen was performed not more often than once a week.

\section{Fermentation measurements}

The production rate of VFA was estimated using an in vitro incubation method according to Carroll and Hungate (1954). Samples of digesta (20 g) were taken from the rumen and diluted immediately with $50 \mathrm{ml}$ of a warm $\left(40^{\circ} \mathrm{C}\right)$ buffer solution composed of $(\mathrm{mg} / 100 \mathrm{ml}):\left(\mathrm{NH}_{4}\right)_{2} \mathrm{SO}_{4}, 45 ; \mathrm{KH}_{2} \mathrm{PO}_{4} 45 ; \mathrm{K}_{2} \mathrm{HPO}_{4} 45 ; \mathrm{NaCl}$, 90; $\mathrm{MgSO}_{4}, 9 ; \mathrm{NaHCO}_{3}, 750$; cysteine hydrochloride, 25; casitone, 100; yeast extract, 100; thioglycolic acid, 0.03 and sterilized rumen fluid, $30 \mathrm{ml}$. The diluted samples were incubated anaerobically at $40^{\circ} \mathrm{C}$ at continuous mixing with a $\mathrm{CO}_{2}$ stream $(60$ $\mathrm{cm}^{3} / \mathrm{min}$ ) for $2 \mathrm{~h}$. Samples for the determination of VFA concentration were taken just before and after 30,60, 90 and 120 min of incubation. The production rate was calculated from the increase in the concentration of the acids.

\section{Eudiplodinium maggii purification}

Purified protozoa were prepared to identify the engulfed material. Samples of rumen contents (about $1 \mathrm{~kg}$ ) were taken from the rumen and diluted with 21 of a warm $\left(40^{\circ} \mathrm{C}\right)$ "caudatum" salt solution (Coleman et al., 1972). The particles were separated by squeezing and discarded whereas, the liquid was placed in a separatory funnel and allowed to stand at $40^{\circ} \mathrm{C}$ for $30 \mathrm{~min}$ to sediment the protozoa. The sediment was transferred into $100 \mathrm{ml}$ centrifuge tubes, diluted with a cold $\left(0^{\circ} \mathrm{C}\right)$ "caudatum " solution to about $80 \mathrm{ml}$ and allowed again to stand in an ice bath to sediment the protozoa. The low temperature was ordered to restrict any digestion of engulfed food during purification of ciliates. After sedimentation, the supernatant was removed by suction, while the sediment was diluted again as described above and the entire procedure was repeated several times, if necessary, whereas the purity of the ciliate suspension was monitored microscopically. Finally, well purified protozoa suspension was adjusted 
to $100 \mathrm{ml}$ with "caudatum" solution and precisely mixed. A $5 \mathrm{ml}$ sample was taken and fixed with aqueous formaldehyde solution $(4 \% \mathrm{v} / \mathrm{v})$ to determine the ciliate concentration, while the remaining part was allowed to stand at $0^{\circ} \mathrm{C}$ for about $30 \mathrm{~min}$. The supernatant fraction was removed by gentle suction, whereas the protozoa - containing sediment was lyophilized and stored at $-30^{\circ} \mathrm{C}$.

Collection and purification of ciliates was begun after the appropriate sampling period (see above) had been finished. Samples of rumen digesta for preparation of purified protozoa were taken just before the morning feeding and 2, 4, 6, 8 and $10 \mathrm{~h}$ after giving the feed to animals. Collection of ciliates was repeated three times in relation to each animal and time point as it had been planed to estimate ADF and NDF inside the cells of ciliates. Sampling of rumen content from the same sheep to prepare purified protozoa was repeated no more than twice a week, thus such a collection period lasted for about 2 months. Purified protozoa were collected when the ciliate fauna of sheep consisted of only Eudiplodinium maggii (experimental period II) and Eudiplodinium maggii + Entodinium caudatum (experimental period III).

Protozoa for enzyme preparation were purified by a similar method. The repeated sedimentation was, however, performed at $40^{\circ} \mathrm{C}$. The purified ciliates were then incubated overnight in the presence of chloramphenicol, ampicilin and streptomycin (each at a concentration of $100 \mu \mathrm{g} / \mathrm{ml}$ ) to kill the intracellular bacteria.

\section{Purified bacteria preparation}

Rumen fluid $(500 \mathrm{ml})$ was collected from the experimental sheep and centrifuged at about $600 \mathrm{x}$ g for $3 \mathrm{~min}$, to separate the protozoa (if present) and small feed particles. The supernatant was collected and centrifuged again at $30.000 \mathrm{x} g$ for 30 min. The supernatant was discarged while the sediment was suspended in cold water $\left(4^{\circ} \mathrm{C}\right)$ and centrifugation was repeated. The purified bacteria were than lyophilized and stored at room temperature.

\section{Sample fixation and storage}

All samples of whole rumen contents for estimation of enzyme activities, DAPA, dry matter (DM), ADF and NDF were stored in polyethylene vials at $-30^{\circ} \mathrm{C}$. Rumen fluid samples taken during the incubation experiments were fixed by addition of a formic acid in a volume equal to $10 \%$ of the conserved sample. They were stored in glass vials at room temperature until the determination of VFA.

Samples of rumen contents for ciliates counts were fixed with $4 \%$ formaldehyde solution added in a proportion of 1:1 (v/v) to the sample and stored at room temperature. 
Enzyme, chemical and microbial analysis

CMC-ase and xylanase activities were measured following extraction of enzymes from the samples of rumen contents and bacteria free Eudiplodinium maggii using $\mathrm{CCl}_{4}$ and lysozyme according to Huhtanen and Khalili (1992). The extracted enzyme preparation was incubated with a solution of either low viscosity CMC (Merck 5064) or birch wood xylan (Sigma X-0502) as described by Groleau and Forsberg (1981) and reducing sugars released from the degraded substrates were quantified using a dinitrosalicylic acid reagent (Millear et al., 1960). The activity of enzymes in rumen digesta was expressed as $\mu \mathrm{M}$ of either glucose or xylose released from the appropriate substrate/g DM of sample/min, respectively. The activity of enzymes in Eudiplodinium maggii was expressed in pM of appropriate products/ciliate cell/min. Glucose and xylose solution of known concentrations of sugars were used as standards.

Diaminopimelic acid (DAPA) was determined quantitatively in bacteria and rumen contents according to Czerkawski (1974).Volatile fatty acids were qualitatively and quantitatively determined by gas chromatography according to Ziołecki and Kwiatkowska (1973). The analysIs were performed using a Philips PU 4410 gas chromatograph.

The dry matter of rumen contents was determined by drying of samples at $105^{\circ} \mathrm{C}$ for $48 \mathrm{~h}$. ADF and NDF in rumen digesta was measured according to AOAC (1990).

All enzymatic and chemical analyses were performed in duplicate on each examined sample.

Identification of ciliate species was performed according to Dogiel (1927) and Grain (1966). Ciliate number was estimated by counting all ciliates present in a $0.1 \mathrm{ml}$ sample according to Michalowski (1975); the fixed material was diluted if necessary. The proportion of cells filled with food particles was estimated in separate counts on samples of purified ciliates. The counting was performed using a light microscope and each sample was counted three times at least.

\section{Statistic}

Student's t-test was used to compare the differences between the mean values (Ruszczyc, 1970).

\section{RESULTS}

\section{Microbe characterization}

The sheep were ciliate free during the first period of the experiment and this was followed by the successive inoculation of Eudiplodinium maggii (period II), 
Entodinium caudatum (period III) and Dasytricha ruminantium (period IV). Due to this, the rumen microfauna of all three animals consisted of a population of one, two and three ciliate species, respectively. Data characterizing the microbial population is presented in Table 1. Of protozoa, the most numerous was Entodinium caudatum, followed by Dasytricha ruminantium. The number of Eudipldodnium maggii was the lowest of all three species established in the rumen $(\mathrm{P}<0.05)$. The establishment of Entodinium caudatum in the rumen (period III) resulted in a decrease in the number of Eudiplodinium maggii in two of three sheep $(\mathrm{P}<0.01)$. No significant changes were observed in the case of the third animal (see sheep 35). The appearance of Dasytricha ruminantium in the rumen (period IV) did not affect the population density of either entodiniomorphid protozoa species.

TABLE 1

Ciliate numbers (x 103/g rumen content) and bacterial mass ( $\%$ DM of rumen digesta) in the rumen of defaunated (period I) and differently faunated (periods II, III, IV) sheep

\begin{tabular}{|c|c|c|c|c|c|}
\hline \multirow{2}{*}{ Sheep No. } & \multirow{2}{*}{$\begin{array}{c}\text { Experimental } \\
\text { periods }\end{array}$} & \multicolumn{3}{|c|}{ Inoculated spices } & \multirow{2}{*}{ Bacteric } \\
\hline & & Eud. maggii & Ent. caudatum & D. ruminantium & \\
\hline \multirow{4}{*}{20} & I & 0 & 0 & 0 & $18.0^{\mathrm{a}}$ \\
\hline & II & $38.5^{\mathrm{a}}$ & 0 & 0 & $19.6^{\mathrm{a}}$ \\
\hline & III & $12.4^{\mathrm{b}}$ & $313.0^{\mathrm{a}}$ & 0 & $13.7^{\mathrm{b}}$ \\
\hline & IV & $15.8^{\mathrm{b}}$ & $334.5^{\mathrm{a}}$ & 52.3 & $12.8^{\mathrm{b}}$ \\
\hline \multirow{4}{*}{33} & I & 0 & 0 & 0 & $13.7^{\mathrm{a}}$ \\
\hline & II & $22.6^{\mathrm{a}}$ & 0 & 0 & $17.9^{\mathrm{b}}$ \\
\hline & III & $11.7^{\mathrm{b}}$ & $375.9^{\mathrm{a}}$ & 0 & $19.6^{\mathrm{b}}$ \\
\hline & IV & $8.5^{\mathrm{b}}$ & $344.4^{\mathrm{a}}$ & 29.8 & $12.7^{\mathrm{a}}$ \\
\hline \multirow{4}{*}{35} & I & 0 & 0 & 0 & $15.8^{\mathrm{a}}$ \\
\hline & II & $15.9^{\mathrm{a}}$ & 0 & 0 & $14.4^{\mathrm{b}}$ \\
\hline & III & $11.8^{\mathrm{ab}}$ & $270.8^{\mathrm{a}}$ & 0 & $12.1^{\mathrm{c}}$ \\
\hline & IV & $10.6^{\mathrm{bc}}$ & $264.5^{\mathrm{a}}$ & 39.8 & $15.5^{\mathrm{ab}}$ \\
\hline
\end{tabular}

mean values $(\mathrm{n}=12)$

values in the column with different letters in superscript differ significantly $(\mathrm{P}<0.05)$

It was found that diaminopimelic acid (DAPA) formed $0.32-0.52 \%$ DM of bacteria and $0.02-0.07 \%$ of rumen digesta. The bacterial mass in the rumen of sheep, which was calculated from these data is also presented in Table 1. The appearance of Eudiplodinium maggii in the rumen resulted in an increase of bacterial mass in two of three animals $(\mathrm{P}<0.05)$. Establishment of Entodinium caudatum and Dasytricha ruminantium positively affect the bacterial population in only one of three examined sheep $(\mathrm{P}<0.05)$, whereas a drop in bacterial mass was observed in the other two $(\mathrm{P}<0.05)$. 
The activity of $\beta$-endoglucanase (CMC-ase) and xylanase varied from 3.8 to $7.0 \mu \mathrm{M}$ of glucose and from 36.1 to $65.3 \mu \mathrm{M}$ xylose released from carboxymethylcellulose and xylan per g DM per min, respectively (Table 2). The activity was the lowest in defaunated sheep and the highest in the animals refaunated with both species from the family Ophryoscolecidae. Establishment of Eudiplodinium maggii in the rumen of sheep resulted in an increase in CMC-ase activity in all three animals $(\mathrm{P}<0.05)$. The appearance of Entodinium caudatum was accompanied by a further increase in this activity $(\mathrm{P}<0.05)$ in two of three sheep but remained unchanged in the last one. Development of Dasytricha ruminantium in the rumen of sheep with established populations of both entodiomorphids resulted in either a decrease (sheep 35) or a decreasing tendency in the activity of CMC-ase.

TABLE 2

The activities of CMC-ase and xylanase ( $\mu \mathrm{M}$ glucose or xylose/g DM/min) in the rumen digesta of defaunated and differently refaunated sheep. Mean values $(n=12)$

\begin{tabular}{|c|c|c|c|c|c|c|}
\hline \multirow{2}{*}{ Animal } & \multirow{2}{*}{ Activity } & \multicolumn{4}{|c|}{ Experimental period } & \multirow{2}{*}{ S.D. } \\
\hline & & I & II & III & IV & \\
\hline \multirow{2}{*}{ Sheep 20} & CMC-ase & $3.9^{\mathrm{a}}$ & $6.3^{\mathrm{b}}$ & $7.0^{\mathrm{c}}$ & $6.6^{\mathrm{bc}}$ & 1.15 \\
\hline & xylanase & $36.1^{\mathrm{a}}$ & $63.1^{\mathrm{b}}$ & $59.3^{\mathrm{b}}$ & $51.1^{\mathrm{c}}$ & 13.44 \\
\hline \multirow{2}{*}{ Sheep 33} & CMC-ase & $4.5^{\mathrm{a}}$ & $6.1^{\mathrm{b}}$ & $6.4^{\mathrm{b}}$ & $5.7^{\mathrm{b}}$ & 1.36 \\
\hline & xylanase & $47.8^{\mathrm{a}}$ & $65.3^{\mathrm{b}}$ & $50.7^{\mathrm{ab}}$ & $47.9^{\mathrm{a}}$ & 14.42 \\
\hline \multirow{2}{*}{ Sheep 35} & CMC-ase & $3.8^{\mathrm{a}}$ & $4.7^{b}$ & $5.9^{\mathrm{c}}$ & $5.2^{\mathrm{b}}$ & 0.97 \\
\hline & xylanase & $38.2^{\mathrm{a}}$ & $45.6^{\mathrm{b}}$ & $44.9^{b}$ & $41.2^{\mathrm{ab}}$ & 6.94 \\
\hline
\end{tabular}

values in a row with different letters differ significantly $(\mathrm{P}<0.05)$

The activity of xylanase was the lowest in the sheep free of protozoa, and the highest in animals refaunated with Eudiplodinium maggii $(\mathrm{P}<0.05)$. Establishment of Entodinium caudatum and then Dasytricha ruminantium was accompanied by a continuous decrease in the activity of this enzyme. The observed decrease was statistically significant in two of three sheep. To examine the role of particular species of ciliates in affecting fibrolytic activity in the rumen of sheep, the correlation coefficient was calculated between the number of ciliates and the activities of both enzymes. A positive and statistically significant relationship was found only between the numbers of Eudiplodinium maggii and the activity of CMCase and xylanase (Figure 1). No relationship was found in the case of Entodinium caudatum or Dasytricha ruminantium, which were much more numerous than Eudiplodinium maggii.

Determination of the protozoal CMC-ase and xylanase extracted from the bacteria free ciliates showed that 6.0 (S.D. \pm 2.11 ) and 77.5 (S.D. \pm 22.11$) \mathrm{pM}$ glucose and xylose were released from carboxymethylcellulose and xylan per cell 


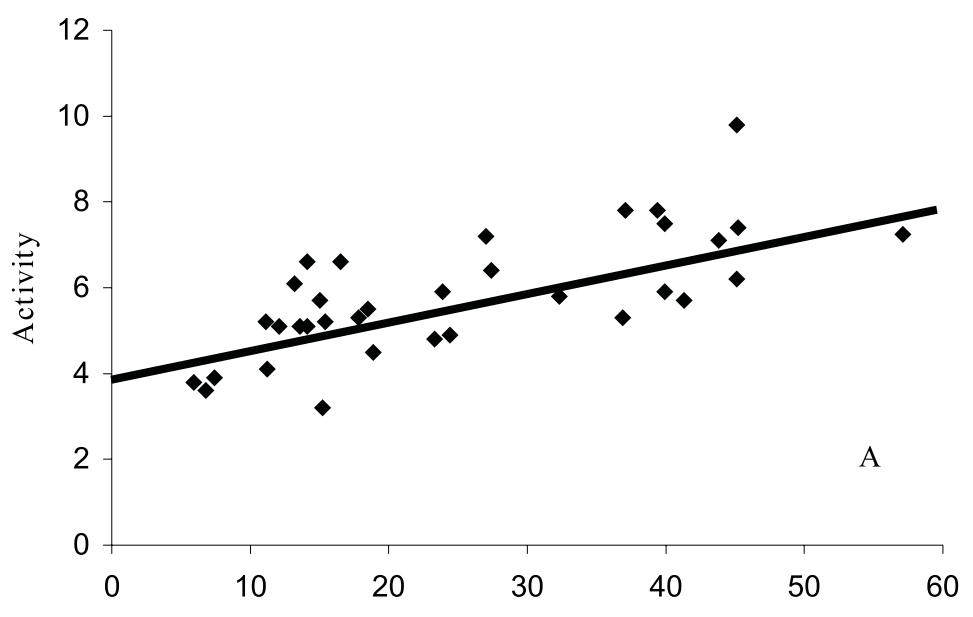

Ciliate numbers

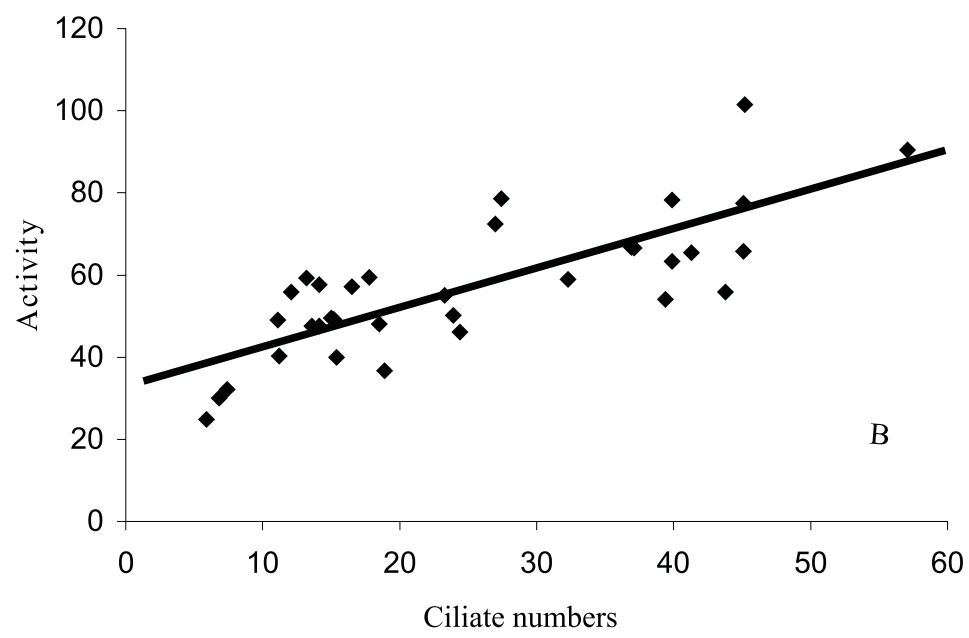

Figure 1. The relationship between the numbers of Eudiplodinium maggii (x10 $/ \mathrm{g}$ rumen digesta) and activity of CMC-ase (A) or xylanase (B), expressed as $\mu \mathrm{M}$ glucose or xylose released from CMC or birch wood xylan/g DM rumen content/min, respectively

of Eudiplodinium maggii per min, respectively. The results presented above and the numbers of protozoa in the rumen digesta were used to calculate the activity of both the Eudiplodinium maggii CMC-ase and xylanase. It was found that these activities varied in the range of 0.52-2.42 and 6.7-31.1 $\mu \mathrm{M}$ glucose and xylose per g DM per min, respectively (Table 3). Thus the enzymes Eudiplodinium maggii contributed to $9-38$ and $14-49 \%$ of total microbial activity of CMC-ase and xylanase in the rumen digesta, respectively. 
TABLE 3

The activity of the Eudiplodinium maggii CMC-ase and xylanase ( $\mu \mathrm{M}$ glucose or xylose/g DM of rumen contants $/ \mathrm{min}$ ) in the rumen digesta of defaunated (period I) and differently refaunated (periods II, III, IV) sheep. Mean values $(\mathrm{n}=12)$

\begin{tabular}{|c|c|c|c|c|c|c|}
\hline \multirow{2}{*}{ Animal } & \multirow{2}{*}{ Activity } & \multicolumn{4}{|c|}{ Experimental periods } & \multirow{2}{*}{ S.D. } \\
\hline & & $\mathrm{I}$ & II & III & IV & \\
\hline \multirow{2}{*}{ Sheep 20} & CMC-ase & 0 & $2.42^{\mathrm{a}}$ & $0.64^{\mathrm{b}}$ & $0.85^{\mathrm{c}}$ & 0.84 \\
\hline & xylanase & 0 & $31.10^{\mathrm{a}}$ & $8.30^{\mathrm{b}}$ & $11.40^{\mathrm{c}}$ & 10.54 \\
\hline \multirow{2}{*}{ Sheep 33} & CMC-ase & 0 & $1.10^{\mathrm{a}}$ & $0.63^{\mathrm{b}}$ & $0.55^{\mathrm{b}}$ & 0.44 \\
\hline & xylanase & 0 & $15.10^{\mathrm{a}}$ & $8.00^{\mathrm{b}}$ & $6.70^{\mathrm{b}}$ & 5.46 \\
\hline \multirow{2}{*}{ Sheep 35} & CMC-ase & 0 & $0.89^{\mathrm{a}}$ & $0.52^{\mathrm{b}}$ & $0.57^{\mathrm{b}}$ & 0.29 \\
\hline & xylanase & 0 & $11.20^{\mathrm{a}}$ & $7.00^{\mathrm{b}}$ & $7.40^{\mathrm{b}}$ & 3.57 \\
\hline
\end{tabular}

values in a row with different letters differ significantly $(\mathrm{P}<0.05)$

\section{Feed digestion and fermentation}

Digesta weight as well as the proportion of ADF and NDF in the rumen content are presented in Table 4. No statistically significant changes in digesta mass were observed in sheep $20(\mathrm{P}>0.05)$, while it increased significantly in sheep 33 when all three ciliate species were present in the rumen $(\mathrm{P}<0.05)$. The weight of rumen contents in sheep 35 increased significantly after establishment of Eudiplodinium

TABLE 4 The weight of rumen contents $(\mathrm{kg})$ as well as ADF and NDF proportions (\% wet weight of rumen digesta) in defaunated (period I) and differently faunated (periods II, III, IV) sheep. Mean values $(\mathrm{n}=9)$

\begin{tabular}{|c|c|c|c|c|c|c|}
\hline \multirow{2}{*}{ Item } & \multirow{2}{*}{ Sheep No } & \multicolumn{4}{|c|}{ Experimental period } & \multirow{2}{*}{ S.D } \\
\hline & & $\mathrm{I}$ & II & III & IV & \\
\hline \multirow{3}{*}{$\begin{array}{l}\text { Rumen } \\
\text { contents } \\
\text { weight }\end{array}$} & 20 & $7.8^{\mathrm{a}}$ & $8.1^{\mathrm{a}}$ & $8.6^{\mathrm{a}}$ & $8.2^{\mathrm{a}}$ & 1.02 \\
\hline & 33 & $11.3^{\mathrm{a}}$ & $10.6^{\mathrm{a}}$ & $11.1^{\mathrm{a}}$ & $13.4^{\mathrm{b}}$ & 1.22 \\
\hline & 35 & $7.4^{\mathrm{a}}$ & $8.5^{\mathrm{b}}$ & $9.1^{\mathrm{b}}$ & $8.7^{\mathrm{b}}$ & 0.74 \\
\hline \multirow{3}{*}{$\mathrm{ADF}$} & 20 & $4.2^{\mathrm{ab}}$ & $3.8^{\mathrm{a}}$ & $4.8^{\mathrm{c}}$ & $4.6^{\mathrm{bc}}$ & 0.54 \\
\hline & 33 & $4.2^{\mathrm{a}}$ & $4.4^{\mathrm{a}}$ & $5.2^{\mathrm{b}}$ & $5.1^{\mathrm{b}}$ & 0.58 \\
\hline & 35 & $4.5^{\mathrm{a}}$ & $4.1^{\mathrm{b}}$ & $4.9^{\mathrm{c}}$ & $4.8^{\mathrm{ac}}$ & 0.58 \\
\hline \multirow{3}{*}{ NDF } & 20 & $6.5^{\mathrm{a}}$ & $5.8^{\mathrm{b}}$ & $7.3^{\mathrm{c}}$ & $7.8^{\mathrm{c}}$ & 0.88 \\
\hline & 33 & $6.7^{\mathrm{a}}$ & $7.0^{\mathrm{a}}$ & $7.5^{\mathrm{ab}}$ & $8.1^{\mathrm{b}}$ & 0.88 \\
\hline & 35 & $7.0^{\mathrm{a}}$ & $6.6^{\mathrm{a}}$ & $7.8^{\mathrm{b}}$ & $7.8^{\mathrm{b}}$ & 0.73 \\
\hline
\end{tabular}

values in a row with different letters differ significantly $(\mathrm{P}<0.05)$ 
maggii $(\mathrm{P}<0.01)$ and did not change significantly following the next two faunations $(\mathrm{P}>0.05)$. The proportion of ADF in the rumen digesta varied from 3.8 to $5.2 \%$. The proportion of this fibre component decreased or did not change after establishment of Eudiplodinium maggii, while appearance of Entodinium caudatum and Dasytricha ruminantium was followed by an increase in ADF content $(\mathrm{P}<0.05)$. Similar changes were also observed in relation to the proportion of NDF in rumen digesta (Table 4).

The mean results characterizing the effect of ciliates inoculated into the rumen of sheep on the digestion of feed, expressed as the disappearance of DM, ADF and NDF from the rumen within $12 \mathrm{~h}$ after feeding are presented in Table 5.They were calculated according to the equation:

where:

$$
\mathrm{Q}_{\mathrm{d}}=\left(\mathrm{RQ}_{\mathrm{r}}+\mathrm{CQ}_{0}\right)-\mathrm{CQ}_{12}
$$

$\mathrm{Q}_{\mathrm{d}} \quad$ - quantity of the examined component that disappeared from the rumen within $12 \mathrm{~h}$ after feeding

$\mathrm{RQ}_{\mathrm{r}}$ - quantity of the examined component in the ration

$\mathrm{CQ}_{0}$ - quantity of the examined component in the rumen content just before feeding

$\mathrm{CQ}_{12}$ - quantity of the examined component in the rumen content at $12 \mathrm{~h}$ after feeding.

TABLE 5

Disappearance of DM, ADF and NDF $(\mathrm{kg} / 12 \mathrm{~h})$ from the rumen defaunated and differently refaunated sheep. Mean values $(n=9)$

\begin{tabular}{|c|c|c|c|c|c|c|}
\hline \multirow{2}{*}{ Item } & \multirow{2}{*}{$\begin{array}{c}\text { Animal } \\
\text { No. }\end{array}$} & \multicolumn{4}{|c|}{ Experimental periods } & \multirow{2}{*}{ S.D. } \\
\hline & & I & II & III & IV & \\
\hline \multirow{3}{*}{$\mathrm{DM}$} & 20 & $0.82^{\mathrm{a}}$ & $0.75^{\mathrm{a}}$ & $0.72^{\mathrm{ab}}$ & $0.63^{\mathrm{b}}$ & 0.110 \\
\hline & 33 & $0.80^{\mathrm{a}}$ & $0.79^{a}$ & $0.72^{\mathrm{ab}}$ & $0.62^{\mathrm{b}}$ & 0.112 \\
\hline & 35 & $0.66^{\mathrm{a}}$ & $0.83^{\mathrm{b}}$ & $0.68^{\mathrm{a}}$ & $0.63^{\mathrm{a}}$ & 0.103 \\
\hline \multirow{3}{*}{$\mathrm{ADF}$} & 20 & $0.32^{\mathrm{a}}$ & $0.30^{\mathrm{a}}$ & $0.26^{\mathrm{a}}$ & $0.18^{\mathrm{b}}$ & 0.071 \\
\hline & 33 & $0.26^{\mathrm{a}}$ & $0.31^{\mathrm{b}}$ & $0.26^{\mathrm{ac}}$ & $0.19^{c}$ & 0.630 \\
\hline & 35 & $0.24^{\mathrm{a}}$ & $0.29^{\mathrm{a}}$ & $0.26^{\mathrm{a}}$ & $0.24^{\mathrm{a}}$ & 0.054 \\
\hline \multirow{3}{*}{ NDF } & 20 & $0.54^{\mathrm{a}}$ & $0.45^{\mathrm{b}}$ & $0.45^{\mathrm{bc}}$ & $0.32^{\mathrm{c}}$ & 0.110 \\
\hline & 33 & $0.52^{\mathrm{a}}$ & $0.50^{\mathrm{a}}$ & $0.44^{\mathrm{a}}$ & $035^{\mathrm{b}}$ & 0.112 \\
\hline & 35 & $0.46^{\mathrm{a}}$ & $0.54^{\mathrm{b}}$ & $0.44^{\mathrm{a}}$ & $0.40^{\mathrm{c}}$ & 0.780 \\
\hline
\end{tabular}

values in a row with different letters differ significantly $(\mathrm{P}<0.05)$

The disappearance of dry matter varied from 0.62 to $0.83 \mathrm{~kg}$ per $12 \mathrm{~h}$. The establishment of Eudiplodinium maggii in the rumen did not change the loss of $\mathrm{DM}$ from the rumen of two sheep $(\mathrm{P}>0.05)$ and increased it markedly in third 
one $(\mathrm{P}<0.01)$. The development of Entodinium caudatum was accompanied by a tendency to decrease (sheep 20 and 33) or a significant drop in the loss of $\mathrm{DM}$ from the rumen $(\mathrm{P}<0.01)$. A decrease to the lowest level was observed after the appearance of Dasytricha ruminantium in the rumen. A similar pattern was observed in the disappearance of ADF from the rumen of sheep 20 and 33. The successive appearance of the populations of three species of ciliates did not affect the quantity of ADF that disappeared from the rumen of sheep 35. The development of successiive ciliate species in the rumen of sheep 20 and 33 was accompanied by a continuous drop in the quantity of NDF which disappeared from the rumen within the $12 \mathrm{~h}$ after the morning feeding. Establishment of Eudiplodinium maggii caused a statistically significant increase in the disappearance of NDF from the rumen of sheep 35. Appearance of Entodinium caudatum and especially Dasytricha ruminantium resulted in a decrease in the pool of NDF, which was lost from the rumen of this animal $(\mathrm{P}<0.01)$.

To study the role of Eudiplodinium maggii in fibre digestion these ciliates were purified and collected to determine the quantity of ADF and NDF inside their cells. Microscopic observation of ciliates after purification showed, however, that the protozoa readily engulfed starch grains. Due to this numerous cells of protozoa were observed to be filled with this polysaccharide (Figure 2). The quantity of starch granules and the number of individuals containing this polysaccharide in endoplasmic sacs decreased successively with time. No increase was, however, observed in the number of protozoa containing fibrous particles in their cells. Such individuals were observed only sporadically. The appearance of Entodinium caudatum in the rumen decreased engulfment of starch by Eudiplodinium maggii but pure ingestion of hay particles remained unchanged.

The concentration of volatile fatty acids in the rumen fluid of sheep is presented in Table 6. The concentrations of acetic, propionic and butyric acids varied within the ranges of 5.25-7.94, $1.29-2.34$ and $0.75-1.39 \mathrm{mM} / 100 \mathrm{ml}$, respectively in relation to the time after feeding and experimental periods. The level of all three examined acids increased at $4 \mathrm{~h}$ after feeding ant this was followed by a continuous decrease. Acetic and propionic acids were the highest when the both entodiniomorphid species were present in the rumen. The highest concentration of butyric acid was, however, found in animals faunated with only Eudiplodinium maggii. The lowest acetate and propionate concentrations were observed after establishment of Eudiplodinium maggii, whereas the lowest butyrate concentrations was found after inoculation all three species of ciliates into the rumen. The establishment of Eudiplodinium maggii in the rumen of defaunated sheep resulted in a decrease or a tendency to decrease in the concentration of acetate and propionate, with the exception of the concentration of the latter $12 \mathrm{~h}$ after feeding. No such effect was observed in relation to butyrate, which was significantly higher at $12 \mathrm{~h}$ after feeding $(\mathrm{P}<0.01)$. Appearance of the second ciliate species (Entodinium caudatum) in the rumen was 

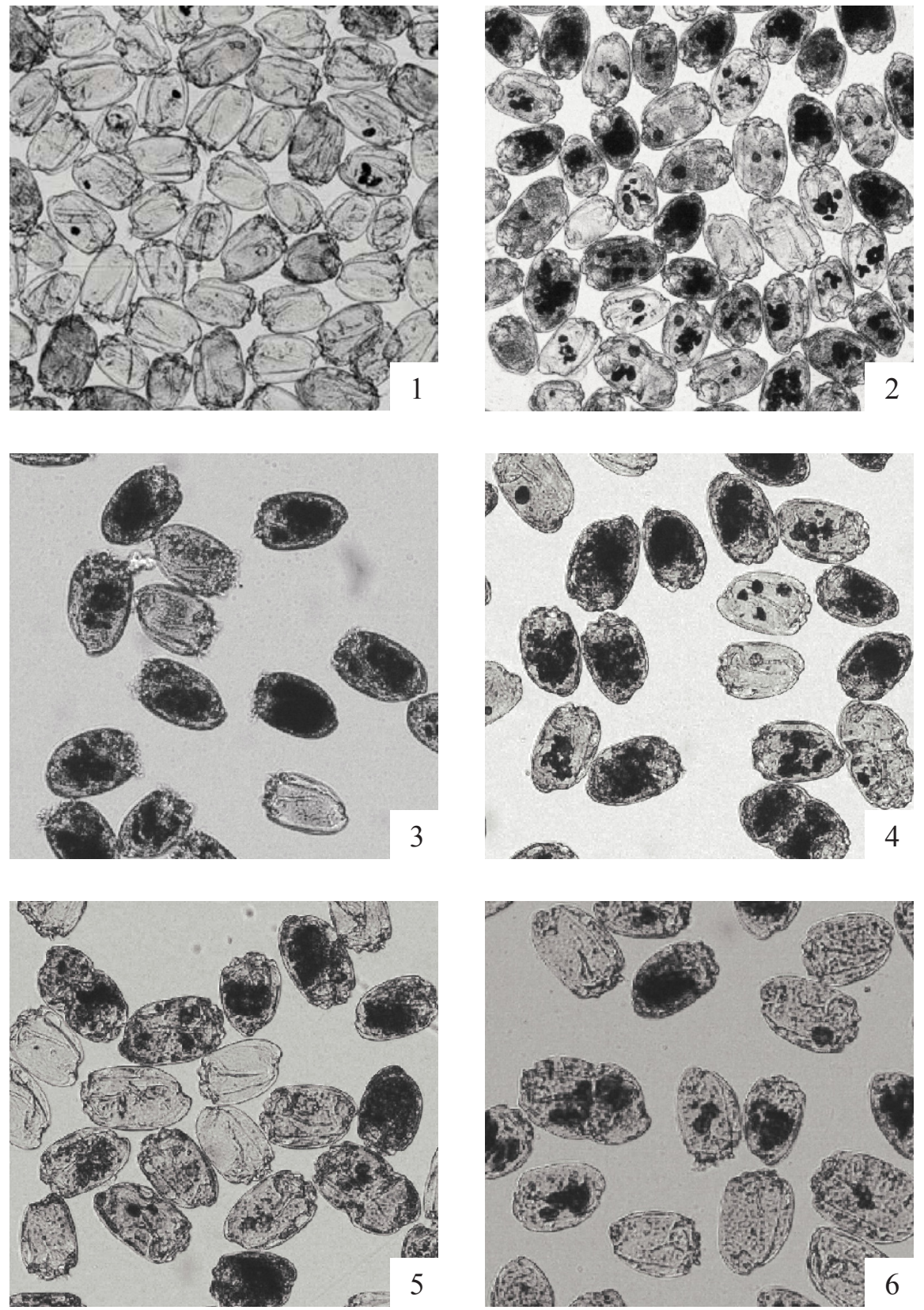

Figure 2. The microscopic photographs of Eudiplodinium maggii taken from the rumen immediately before the morning feeding (1) as well was at two (2), four (3), six (4), eight (5) and ten (6) hours after feeding. Black colored particles in the cells of protozoa are starch grains engulfed by ciliates following reaction with iodine in potassium iodide 
TABLE 6

The concentration of volatile fatty acids $(\mu \mathrm{M} / 100 \mathrm{ml})$ in the rumen fluid of defaunated (period I) and differently faunated (periods II, III, IV) sheep. Mean values $(\mathrm{n}=27)$

\begin{tabular}{|c|c|c|c|c|c|c|}
\hline \multirow{2}{*}{ Acids } & \multirow{2}{*}{$\begin{array}{l}\text { Hours after } \\
\text { feeding }\end{array}$} & \multicolumn{4}{|c|}{ Experimental period } & \multirow{2}{*}{ S.D. } \\
\hline & & I & II & III & IV & \\
\hline \multirow{4}{*}{ Acetic } & 0 & $5.73^{\mathrm{a}}$ & $5.25^{\mathrm{ac}}$ & $7.20^{\mathrm{b}}$ & $5.98^{\mathrm{c}}$ & 0.842 \\
\hline & 4 & $6.97^{\mathrm{a}}$ & $6.50^{\mathrm{a}}$ & $7.94^{b}$ & $6.92^{\mathrm{a}}$ & 0.703 \\
\hline & 8 & $6.60^{\mathrm{a}}$ & $6.09^{b}$ & $7.73^{c}$ & $6.38^{\mathrm{ab}}$ & 0.859 \\
\hline & 12 & $5.69^{\mathrm{a}}$ & $5.87^{\mathrm{a}}$ & $6.73^{\mathrm{bc}}$ & $6.48^{c}$ & 0.673 \\
\hline \multirow{4}{*}{ Propionic } & 0 & $1.62^{\mathrm{a}}$ & $1.29^{\mathrm{b}}$ & $1.74^{\mathrm{a}}$ & $1.39^{\mathrm{b}}$ & 0.234 \\
\hline & 4 & $2.16^{\mathrm{ab}}$ & $2.12^{\mathrm{ab}}$ & $2.34^{\mathrm{a}}$ & $1.87^{\mathrm{b}}$ & 0.289 \\
\hline & 8 & $1.96^{\mathrm{a}}$ & $1.77^{\mathrm{b}}$ & $1.94^{\mathrm{a}}$ & $1.58^{\mathrm{b}}$ & 0.244 \\
\hline & 12 & $1.69^{\mathrm{a}}$ & $1.62^{\mathrm{ab}}$ & $1.67^{\mathrm{ab}}$ & $1.50^{\mathrm{b}}$ & 0.152 \\
\hline \multirow{4}{*}{ Butyric } & 0 & $0.89^{\mathrm{a}}$ & $0.80^{\mathrm{ac}}$ & $1.06^{\mathrm{b}}$ & $0.75^{\mathrm{c}}$ & 0.148 \\
\hline & 4 & $1.27^{\mathrm{a}}$ & $1.39^{\mathrm{a}}$ & $1.29^{\mathrm{a}}$ & $0.96^{\mathrm{b}}$ & 0.198 \\
\hline & 8 & $1.13^{\mathrm{a}}$ & $1.15^{\mathrm{a}}$ & $1.16^{\mathrm{a}}$ & $0.89^{\mathrm{b}}$ & 0.169 \\
\hline & 12 & $0.85^{\mathrm{a}}$ & $1.14^{\mathrm{b}}$ & $1.02^{\mathrm{c}}$ & $0.88^{\mathrm{a}}$ & 0.158 \\
\hline
\end{tabular}

values in a row with different letters differ significantly $(\mathrm{P}<0.05)$

TABLE 7

The production rate of volatile fatty acids $(\mu \mathrm{M} / \mathrm{g}$ rumen content $/ \mathrm{h})$ in the rumen contents of defaunated (period I) and differently faunated (periods II, III, IV) sheep. Mean values ( $\mathrm{n}=27)$

\begin{tabular}{|c|c|c|c|c|c|c|}
\hline \multirow{2}{*}{ Acids } & \multirow{2}{*}{$\begin{array}{l}\text { Hours after } \\
\text { feeding }\end{array}$} & \multicolumn{4}{|c|}{ Experimental period } & \multirow{2}{*}{ S.D } \\
\hline & & $\mathrm{I}$ & II & III & IV & \\
\hline \multirow{3}{*}{ Acetic } & 0 & $22.1^{\mathrm{a}}$ & $21.5^{\mathrm{a}}$ & $21.3^{\mathrm{a}}$ & $21.5^{\mathrm{a}}$ & 2.82 \\
\hline & 4 & $23.8^{\mathrm{a}}$ & $23.4^{\mathrm{a}}$ & $24.2^{\mathrm{a}}$ & $24.2^{\mathrm{a}}$ & 2.07 \\
\hline & 8 & $23.9^{\mathrm{a}}$ & $22.4^{\mathrm{a}}$ & $23.4^{\mathrm{a}}$ & $24.5^{\mathrm{a}}$ & 3.66 \\
\hline \multirow{3}{*}{ Propionic } & 0 & $4.9^{\mathrm{a}}$ & $5.4^{\mathrm{a}}$ & $4.7^{\mathrm{a}}$ & $4.8^{\mathrm{a}}$ & 0.81 \\
\hline & 4 & $6.5^{\mathrm{a}}$ & $5.6^{\mathrm{a}}$ & $6.6^{\mathrm{a}}$ & $5.1^{\mathrm{b}}$ & 1.13 \\
\hline & 8 & $6.0^{\mathrm{a}}$ & $5.1^{\mathrm{a}}$ & $5.3^{\mathrm{a}}$ & $5.5^{\mathrm{a}}$ & 0.97 \\
\hline \multirow{3}{*}{ Butyric } & 0 & $3.5^{\mathrm{a}}$ & $3.5^{\mathrm{ab}}$ & $3.1^{\mathrm{bc}}$ & $2.8^{\mathrm{c}}$ & 0.47 \\
\hline & 4 & $3.7^{\mathrm{a}}$ & $5.6^{\mathrm{b}}$ & $4.1^{\mathrm{a}}$ & $3.8^{\mathrm{a}}$ & 0.70 \\
\hline & 8 & $4.0^{\mathrm{a}}$ & $3.9^{\mathrm{a}}$ & $3.9^{\mathrm{a}}$ & $3.9^{\mathrm{a}}$ & 0.54 \\
\hline
\end{tabular}

values in a row with different letters differ significantly $(\mathrm{P}<0.05)$

accompanied by an increase in the concentration of acetic and propionic acids, while an increase in butyrate was observed only just before the morning feeding $(\mathrm{P}<0.05)$. The development of Dasytricha ruminantium in the rumen resulted in 
a decrease of all three acids ( $\mathrm{P}<0.05)$. No change was only found in the level of acetic acid $12 \mathrm{~h}$ after feeding.

The results of measuring the production rate of VFA are described in Table 7. The production rates of acetic, propionic and butyric acids varied in the range of 21.2-24.5, 4.7-6.6 and 2.8-5.6 $\mu \mathrm{M} / \mathrm{g}$ rumen contents/h. Establishing Eudiplodinium maggii in the rumen of defaunated sheep resulted in a significant increase in the production rate of butyrate at $4 \mathrm{~h}$ after feeding $(\mathrm{P}<0.001)$. Neither production of acetate not propionate was affected. Appearance of Entodinium caudatum was accompanied by a decrease in the production rate of butyric acid just before the morning feeding when compare with defaunated animals. Establishment of Dasytricha ruminantium in the sheep containing both ophryoscolecids resulted in a decrease in the rate of production of both propionic $(\mathrm{P}<0.05)$ and butyric acids $(\mathrm{P}<0.01)$ at $4 \mathrm{~h}$ after feeding and directly before the morning meal, respectively.

\section{DISCUSSION}

The sheep were faunated with three species of ciliates that differ from each other in their carbohydrate requirements. Both entodiniomorphid species ingest starch, but Entodinium caudatum is clearly the starch-preferring protozoan, while Eudiplodinium maggii also readily utilizes fibrous food (Williams, 1988; Dehority, 1993; Michałowski, 1997, 2001). It can be assumed that the appearance of numerous Entodinium caudatum ciliates in the rumen of sheep resulted in the reduction of a marked part of starch that was available to Eudiplodinium maggii when this protozoan was alone in the rumen and this could result in a drop in their numbers. Conversely Dasytricha ruminantium utilize only soluble carbohydrates (Van Hoven and Prins, 1977). Thus, the establishment of population of this organisms did not lead to development of carbohydrate competition between the ciliate species harbored in the rumen. Due to this, the quantity of carbohydrates utilized by Eudiplodinium maggii and Entodinium caudatum might have remained unchanged and no drop in the population density of ophryoscolecids was observed. It is obvious that the considered relationship can not be the only one that affected ciliate numbers in the rumen.

It is well known that ciliates reduce the number of bacteria in the rumen (Coleman, 1988). The results presented in this report suggest that small ciliates, like Entodinium caudatum and Dasytricha ruminantium, were more effective in exerting a negative effect on bacterial flora than the large ciliates Eudiplodinium maggii. On the other hand, however, this effect was, to some extent, host-animal specific.

It was found that the establishment of Eudiplodinium maggii in the rumen resulted in on increase in the total activity of both CMC-ase and xylanase in the 
rumen. These results are in good agreement with the earlier findings of Coleman (1985) and Michalowski and Harmeyer (1998). One of possible explanations for this finding seems to be the ability of this species of ciliates to synthesize both types of enzymes. It was calculated in this study that each protozoan was able to release 6 and $77.5 \mathrm{pM}$ of glucose and xylose per minute from CMC and xylan, respectively. It was also calculated that up to $38 \%$ of total CMC-ase and $49 \%$ xylanase in the rumen originated from Eudiplodinium maggii cells, respectively, and this contribution was visibly related to the number of ciliates. This finding supports the thesis that Eudiplodinium maggii can directly affect fibrolytic activity in the rumen by participation in the production of such enzymes as $\beta$-edoglucanase and xylanase.

The appearance of Entodinium caudatum in the rumen of sheep resulted in a further increase in the activity of CMC-ase, in spite of the significant drop in the numbers of Eudiplodinium maggii. Such a finding can be explained by the positive influence of fibrolytic microflora (Ushida et al., 1991) rather than by involvement of this protozoan in cellulose degradation as no cellulolytic activity has been detected in Entodinium caudatum cells to date (Williams, 1988). In contrast to CMC-ase, the activity of xylanase decreased in the presence of Entodinium caudatum similarly as did the concentration of Eudiplodinium maggii. This can suggest that the activity of xylanase in the rumen was more closely related to the presence and the number of this latter ciliate than the CMC-ase. Further studies seem to be necessary to confirm and explain this phenomenon.

The appearance of Dasytricha ruminantium was accompanied by a drop in CMC-ase activity and especially in that of xylanase. Such a reaction could result from the restricting effect of these protozoa upon fibrolytic bacteria. The obtained results confirm such a suggestion only in relation to total bacterial mass, as fibrolytic bacteria were not measured. A negative effect of ruminal holotrich ciliates on the fibrolytic microflora has been, however, also reported (Ushida et al., 1991).

Rumen content volume varied in relation to the animal rather than to microfauna composition. On the other hand, the proportion of ADF and NDF in the rumen contents increased after appearance of Entodinium caudatum and Dasytricha ruminantium in the sheep. This finding suggests a decrease in digestion of these components of dietary fibre and is in good accordance with the calculated quantities of dry matter as well as ADF and NDF that disappeared from the rumen of sheep during $12 \mathrm{~h}$ after feeding (Table 6). The results presented in Table 6 show that the appearance of Dasytricha ruminantium in the rumen of sheep with developed populations of Eudiplodinium maggii and Entodinium caudatum resulted in a significant drop in the quantities of DM, ADF and NDF, which disappeared from the rumen. Thus these findings are in good agreement with results obtained in in sacco experiments (Michałowski et al., 2002) and support the opinion of Ushida et al. (1991) on the restricting effect of rumen Holotricha on fibre digestion. 
In contrast to this Jouany et al. (1995) observed an increase in ADF digestion following establishment of Isotricha in the rumen of defaunated sheep. More recently Ivan et al. (2000) were developing population of Dasytricha ruminantium in the rumen of sheep and found that the effect of this species of protozoa upon stomach digestibility of NDF was depended on the diet. A tendency to decrease NDF digestion was observed there when a haycrop based diet was given to animals. The cited authors also found that inoculation of ciliates from the genus Entodinium to the rumen of defaunated sheep led to an improvement in the digestion of the mentioned component of fibre. This finding is contradictory to the results presented in this report. However, the diet given here to the sheep was also quite different from that in the cited paper.

One of the objectives of this study was to determine the involvement of the fibrolytic Eudiplodinium maggii (Dehority, 1993; Michałowski, 1997) in digestion of fibrous feed. For this purpose, purified protozoa were collected for a period of $10 \mathrm{~h}$ after feeding to determine the quantity of ADF and NDF in the cells of these organisms. Microscopic examination showed, however, that these ciliates readily engulfed starch grains (see Figure 2) while small fibrous particles were observed only very sporadically inside the cells of protozoa. These findings precluded any sense of the determination mentioned above. They suggest that direct involvement of Eudiplodinium maggii in fibre digestion was rather poor. This suggestion can be used to explain the disagreement between the changes in the activity of $\beta$ endoglucanase and xylanase on the one side, and in the disappearance of DM, $\mathrm{ADF}$ and NDF on the other that were found after establishment of Eudiplodinium maggii in the rumen of sheep. It is also worth emphasizing that such results were not expected since the same ciliates that were used for the inoculation of sheep readily engulfed, digested and intensively fermented hay in vitro (Michałowski, 2001). Powdered hay was, however, used in the cited experiment. It is possible that the concentration of the small particles of hay in the rumen fluid of sheep was too low to be engulfed by these ciliates especially when starch grains were also present there.

The concentration of VFA changed in relation to the microfauna composition and establishment of Eudiplodinium maggii in the rumen of defaunated sheep was accompanied by drop or a tendency to lower the level of acetate and propionate. The concentration of these acids increased when Entodinium caudatum was added to the rumen. In contrast to acetate and propionate, the level of butyrate did not decrease. It seems probable that the mentioned changes resulted from changes in the fermentation pattern of starch after refaunation of sheep with Eudiplodinium maggii and Entodinium caudatum, as the protozoa of both species engulfed large quantities of this polysaccharide. It was found in earlier studies that two main end products in carbohydrate metabolism of Eudiplodinium maggii are acetic and butyric acids, while Entodinium caudatum produce rather acetate and propionate 
(Williams, 1988; Williams and Coleman, 1992; Michałowski, 1997, 2001). This suggestion is in accordance with the results of determination of the production rate of the acids. It was found there that establishing of Eudiplodinium maggii in the rumen of sheep resulted in a significant increase in the production rate of butyrate at $4 \mathrm{~h}$ after feeding. Appearance of Dasytricha ruminantium in the rumen resulted in a drop in the concentration of all acids and this was accompanied by a decrease in the production rate of propionate at $4 \mathrm{~h}$ after feeding and of butyric acid just before giving feed to the animals. No changes in the population density of the latter two species were simultaneously observed, thus the observed changes in volatile fatty acids perhaps resulted from changes in bacterial flora. This suggestion is in good accordance with the opinion of Ivan et al. (2000) related to the responsibility of bacteria for the changes in the proportion of particular acids in the rumen.

\section{REFERENCES}

AOAC, 1990. Association of Official Analytical Chemists, Official Methods of Analysis. $15^{\text {th }}$ Edition. Arlington, VA

Carroll E.J., Hungate R.E., 1954. The magnitude of the microbial fermentation in the bovine rumen. Appl. Microbiol. 2, 205-214

Coleman G.S., 1985. The cellulase content of 15 species of entodiniomorphid protozoa, mixed bacteria and plant debris isolated from the ovine rumen. J. Agr. Sci. 104, 349-360

Coleman G.S., 1988. Protozoal-bacterial interaction in the rumen. In: J.V. Nolan, R.A. Leng, D.I. Demeyer (Editiors). The Roles of Protozoa and Fungi in Ruminant Digestion. Penambul Books, Armidale NSW, pp. 13-27

Coleman G.S., Davies J.I., Cash M.A., 1972. The cultivation of the rumen ciliates Epidinium ecaudatum caudatum and Polyplastron multivesiculatum in vitro. J. Gen. Microbiol. 75, 509-521

Czerkawski J.W., 1974. Methods dor determining 2,5 diaminopimelic acid and 2-aminoethylphosphonic acid in gut contents. J. Sci. Food. Agr. 25, 45-55

Dehority B.A., 1993. Microbial ecology of cell wall fermentation. In: H.G. Jung, D.R. Buxton, R.D. Hatfield, J. Ralf (Editors). Forage Cell Wall Structure and Digestibility. ASA, Inc. CSSA, Inc. SSSA,Inc. Madison, Wisconsin, pp. 425-453

Dogiel V.A., 1927. Monographie der Familie Ophryoscolecidae. Arch. Protistkd. 59, 1-288

Grain J., 1966. Étude cytologique de quelques ciliés holotriches endocommensaux des ruminants et des équidés (Primière partie). Protistologica 2, 59-141

Groleau D., Forsberg C.W., 1981. Cellulolytic activity of the rumen bacterium Bacteroides succinogenes. Can. J. Microbiol. 27, 517-530

Huhtanen P.P., Khalili H., 1992. The effect of sucrose supplements on the particle associated carboxymethylcellulase (EC 3.2.1.4) and xylanase (EC 3.2.1.8) activities in cattle given grasssilage-based diet. Brit. J. Nutr. 67, 245-255

Ivan M., Neil, L., Forster R., Alimon R., Rode L.M., Entz T., 2000. Effect of Isotricha, Dasytricha, Entodinium and total fauna on ruminal fermentation and duodenal flow in wethers fed different diets. J. Dairy Sci. 83, 776-787 
Jouany J.P., Ushida K., 1990. Protozoa and fibre digestion in the rumen. In: S. Hoshino, R. Onodera, H. Minato, H. Itabashi (Editors). The Rumen Ecosystem. Japan Scientific Press, Tokyo, Springer Verlag, Berlin, pp. 139-150

Jouany J.P., Sénaud J., Toillon S., Ben Salah M., Bohatier J., Prensier G., 1995. Effect of inoculation of Isotricha alone or a mixed B-type fauna in a defaunated rumen on the digestion of hay-maize $\operatorname{diet}$ (70:30) in sheep. Reprod. Nutr. Develop. 35, 11-25

Michałowski T. 1975. The effect of certain feedingstuffs on rumen ciliate protozoa in vitro. J. Agr. Sci. $85,151-158$

Michałowski T., 1997. Digestion and fermentation of the microcrystalline cellulose by the rumen ciliate protozoon Eudiplodinium maggii. Acta Protozool. 36, 181-185

Michałowski T., 2001. The in vitro digestion and fermentation of hay by the rumen ciliates Eudiplodinium maggii. Ann. Warsaw Agr. Univ., Anim. Sci., Special Number, pp. 138-147

Michałowski T., Bełżecki G., Pająk J.J., 2002. Use of nylon bags of different porosity to study the role of different groups of rumen ciliates in in situ digestion of hay in sheep. J. Anim. Feed Sci. $11,611-625$

Michalowski T., Harmeyer J., 1998. The effect of rumen ciliates Eudiplodinium maggii on the xylanase and CMC-ase activity in sheep. In: J.A.M. van Arendonk (Editor). Book of Abstracts of the $49^{\text {th }}$ Annual Meeting of the European Association for Animal Production. Wageningen Pers, Wageningen, p. 86

Michałowski T., Harmeyer J., Bełżecki G., 1999. The importance of washing the omasum for successful defaunation of sheep. J. Anim. Feed Sci. 8, 611-619

Michałowski T., Muszyński P., Landa I., 1991. Factors influencing the growth of rumen ciliates Eudiplodinium maggii in vitro. Acta Protozool. 30, 115-120

Miller G.L., Blum R., Glennon W.E., Burton A.L., 1960. Measurement of carboxymethylcellulase activity. Analyt. Biochem. 2, 127-132

Ruszczyc Z., 1970. Methodology of Zootechnical Experiments (in Polish). PWRiL, Warszawa

Ushida K., Jouany J.P., Demeyer D., 1991. Effects of presence or absence of rumen protozoa on the efficiency of utilization of concentrate and fibrous feeds. In: T.Tsuda, Y. Sasaki, R. Kawashima (Editors). Physiological Aspects of Digestion and Metabolism in Ruminants. Academic Press Inc., San Diego, pp. 525-564

Van Hoven W., Prins R.A., 1977. Carbohydrate fermentation by the rumen ciliate Dasytricha ruminantium. Protistologica 13, 599-606

Williams A.G., 1988. Metabolic activity of rumen protozoa. In: J.V. Nolan, R.A. Leng, D.I. Demeyer (Editors). The Roles of Protozoa and Fungi in Ruminant Digeston. Penambul Books, Armidale NSW, pp. 97-126

Williams A.G., Coleman G.S., 1992. The Rumen Protozoa. Springer Verlag, New York, Berlin

Ziołecki A., Kwiatkowska E., 1973. Gas chromatography of C1 to C5 fatty acids in the rumen fluid and fermentation media. J. Chromatogr. 80, 250-254 


\section{STRESZCZENIE}

\section{Wpływ selektywnie dobieranej fauny żwaczowej na aktywność enzymów fibrolitycznych, biomasę bakterii, ubytki wlókna oraz typ fermentacji u owiec}

Trzy tryki rasy merynos polski, żywione sianem i śrutą jęczmienna, zdefaunowano, a następnie refaunowano wyłącznie Eudiplodinium maggii albo Eudiplodinium maggii i Entodinium caudatum lub obydwoma wymienionymi gatunkami orzęsków i Dasytricha ruminantium. Ogólna liczba orzęsków wahała się od 16 do $403 \times 10^{3} / \mathrm{g}$ treści żwacza w zależności od okresu badań, a biomasa bakterii stanowiła od 12,7 do19,6\% suchej masy treści. Biomasa bakterii u dwóch, spośród trzech owiec, obniżyła się po rozwoju Entodinium caudatum i Dasytricha ruminantium w żwaczu, natomiast rozwój Eudiplodinium maggii stymulował rozwój mikroflory. Ustalenie się mikrofauny Ophryoscolecidae spowodowało wzrost aktywności CMC-azy i ksylanazy $(\mathrm{P}<0,01)$, natomiast pojawieniu się Dasytricha ruminantium towarzyszł spadek aktywności ksylanolitycznej. Stwierdzono dodatnią korelację między liczebnością Eudiplodinium maggii a aktywnością CMC-azy i ksylanazy, niezależnie od obecności lub braku innych pierwotniaków w żwaczu. Wykazano, że ubytek suchej masy, ADF i NDF ze żwacza w ciagu 12 godz. po karmieniu wyniósł 0,62-0,83; 0,18-0,32 i 0,32-0,54 kg, odpowiednio. Pojawienie się Eudiplodinium maggii w żwaczu spowodowało wzrost ubytku badanych składników tylko u jednego spośród trzech zwierząt. Zmniejszenie się ubytków stwierdzono natomiast u wszystkich trzech owiec po pojawieniu się Dasytricha ruminantium. Stężenie kwasu octowego, propionowego i masłowego wynosiło 5,25-7,95, 1,29-2,34 i 0,75-1,34 mM/100 ml płynu żwacza, odpowiednio. Najmniej octanu i propionianu stwierdzono u owiec z rozwiniętą populacją Eudiplodinium maggii, zaś maślanu u zwierząt mających wszystkie 3 gatunki pierwotniaków w żwaczu. Największe stężenie kwasu octowego stwierdzono po zadomowieniu się obydwóch gatunków z rzędu Entodiniomorphida, a masłowego w obecności jedynie Eudiplodinium maggii. Wykazano, że produkcja kwau octowego nie zależała od obecności pierwotniaków. Produkcja maślanu w 4 godzinie po karmieniu zwiększyła się w obecności Eudiplodinium maggii. Pojawienie się Entodinium caudatum i Dasytricha ruminantium powodowało spadek produkcji kwasu masłowego w 4 godz po karmieniu i kwasu propionowego przed karmieniem. 